\title{
ANALISIS FAKTOR-FAKTOR YANG MEMPENGARUHI KEPUASAN KONSUMEN TERHADAP KOPI ARABIKA LOLO PADA KAFE GUBUK COFFEE CENTRAL DI PAYAKUMBUH
}

\section{Analysis Of Factors That Influence Customer Satisfaction Of Lolo Arabica Coffee In Coffee Central Shop Cafe In Payakumbuh}

\author{
Laelatul Rahmi ${ }^{1}$, Hasnah $^{2}$, Lora Triana ${ }^{3}$ \\ ${ }^{1}$ Mahasiswa Program Studi Agribisnis Fakultas Pertanian Universitas Andalas, Padang \\ ${ }^{2}$ StaffPengajar Program Studi Agribisnis Fa kultas Pertanian Universitas Andalas, Pa dang \\ ${ }^{3}$ Staff Pengajar Program Studi Agribisnis Fa kultas Pertanian Universitas Andalas, Padang \\ *email koresponden: la elatulrahmi2@gmail.com
}

\begin{abstract}
Abstrak
Tujuan penelitia n inia dalah (1) mendeskripsikan gambaran kepuasan konsumen minuman kopi Arabika Lolo berdasarkan bauran pemasaran pada kafe Gubuk Coffee Central (2) menganalisis faktor-faktor y ang m empengaruhi kepuasan konsumen terhadap minuman kopi Arabika Lolo pada kafe Gubuk Coffee Central. Penelitian ini dilakukan pada 9 Mei-9 Juni 2019. Data yang digunakan adalah data primer dan data sekunder. Penelitia $n$ ini men ggu nakan metode survei. Metode pengambila n sampel menggunakan rumus slovin sehingga sa mpel yang digunakan berjumlah 97 responden. Data dia nalisis secara deskriptif kuantitatif. Hasil analisis menunjukkan bahwa (1) Tingkat kepuasan konsumen minuman kopi Arabika Lolo pada Ka fe Gubuk Coffee Central berada pada kategori puas dengan nilai skor rata-rata seb e sar 4, 18. Jika dilihat darivaria bel ba uran pemasaran diketahuibahwa semua variabel memilikinila iskor rata-rata yang berada pada ka tegori baik untuk variabel produk, tempat, dan harga, dan kategori sangat baik untuk variabel harga. (2) B erdas arkan ha sil analisis diketahui bahwa variabel y ang berpengaruh signifikan terhadap kepuasan konsumen minuman kopi Arabika Lolo a dalah variabel produk dan variabel harga, sedangkan variabel tempat dan variabel promosi tid ak be rpengaru h signifikan terhadap kepuasan konsumen minuman kopi Arabika Lolo.
\end{abstract}

Kata kunci: kopi, a rabika lolo, kepuasan konsumen, bauran pemasaran.

\begin{abstract}
The purpose of this study are to (1) describe the description of consumer satisfaction Lolo Arabika Coffee drinks ba sed on the marketing mix at GubukCoffee Central Cafe (2) analyze the factors that influence consumer satisfaction with Lolo Arabica coffee drinks at Gubuk Coffee Central cafe. This research was conducted on May 9 to June 9 2019. The data used are primary data and secondary data. This research uses surveymethod. The sampling method uses the Slovin formula so that the sample used is 97 respondents. Data were analyzed quantitativedescriptive. The analysis shows that (1) The level of consumer satisfaction ofLolo Arabica coffee drinks at Cafe GubukCoffee Central is in the satisfied category with an average score of 4.18. When viewed from the ma rketing mix variable it is known that all variables have an average score value that is in both categories for product, place, and price variables, andvery good cate gories for price variables. (2) Based on the results of the analysis it is known that the variables that have a significant effect on customer satisfaction of Lolo Arabica coffee drinks are product variables and price variables, while the place va riables and promotion variables haveno significant effecton consumer satisfaction of Lolo Arabica coffee drinks
\end{abstract}

Keywords: coffee, arabica lolo, consumer satisfaction, marketing mix. 


\section{PENDAHULUAN}

Sektor pertanian Nasional, khususnya subsektor tanaman perkebunan, memiliki komoditi-komoditi unggulan yang telah mendunia. Salah satu komoditi perkebunan yang potensial untuk dikembangkan ialah kopi. Berdasarkan catatan Asosiasi Eksportir Kopi Indonesia (AEKI, 2018) dari 10 negara penghasil kopi terbesar di dunia, Indonesia merupakan produsen kopi terbesar ke empat di dunia setelah Brazil, Vietnam, dan Columbia. Luas areal perkebunan kopi Indonesia saat ini mencapai 1,2 juta hektar dengan produksi rata-rata per tahun sekitar 600.000 ton. Dari luas areal tersebut , 96\% merupakan lahan perkebunan kopi rakyat dan $4 \%$ sisanya merupakan milik perkebunan swasta dan pemerintah (PTP Nusantara). Kopi menjadi potensial untuk dikembangkan karena kebutuhan akan kopi semakin meningkat, baik di dalam maupun di luar negeri.

Menurut (Adityo, 2014.) perkembangan konsumsi masyarakat terhadap kopi memberikan peluang bagi para investor lokal dan asing untuk menanamkan modalnya dalam industri kopi. Investasi dalam industri kopi tidak hanya terbatas pada produksi biji kopi dan pemanggangan biji kopi saja, akan tetapi semakin berkembang ke tahap penyajian kopi kepada konsumen.

Hadir dan berkembangnya bisnis coffee shop dan coffee roastery merupakan salah satu akibat dari perubahan gaya hidup masayarakat. Coffee shop menjadi tempat interaksi sosial dan gaya hidup anak muda saat ini. Coffe shop tidak hanya berfungsi sebagai tempat untuk menikmati kopi, tetapi telah menjadi sebuah tempat berkumpul, bersosialisasi, hiburan, produktivitas, dan kegiatan bisnis yang secara berkala dilakukan baik secara individu maupun kelompok. Perkembangan industri kedai kopi menyebabkan semakin intensnya persaingan antar kedai kopi untuk menarik dan mempertahankan konsumen agar loyal.
Gubuk Coffee merupakan suatu waralaba lokal (franchise) coffee shop dan roastery pertama di Sumatera Barat dengan menerapkan sistem tanpa royalti (royalty fee) pada omset masing-masing cabang. Gubuk Coffee Central yang terletak di Jalan Sudirman No.75 kelurahan Balai Gadang Koto Nan Gadang Payakumbuh Utara, Kota Payakumbuh merupakan gerai Gubuk Coffee pertama yang didirikan dan dikelola langsung oleh pewaralaba (franchisor). Gubuk Coffee Central menawarkan kopi-kopi asli yang berasal dari berbagai pelosok Nusantara, yang terdiri dari dua belas jenis kopi. Kopi tersebut terdiri dari sebelas jenis kopi Arabika dan satu jenis kopi Robusta. Kopi Arabika Lolo menempati peringkat pertama konsumsi bahan baku pada tahun 2018. Hal tersebut menunjukkan bahwa kopi yang paling diminati dan paling disukai oleh para konsumen pada kafe Gubuk Coffee Central adalah kopi Arabika Lolo. Oleh karena itu, peneliti memfokuskan objek penelitian terhadap kopi unggulan dari Gubuk Coffee Central yaitu kopi Arabika Lolo. Peneliti ingin meneliti faktor-faktor apa sajakah yang mempengaruhi kepuasan kosumen terhadap kopi Arabika Lolo ini. Kopi Arabika Lolo ini diolah menjadi beberapa macam menu pada Gubuk Coffee Central diantaranya yaitu : Vietnam Drip Coffee Original, Vietnam Drip Coffee Milk, Gubuk Coffee Original, dan Gubuk Coffee Milk. Kopi Arabika Lolo berasal dari Nagari Lolo kecamatan Pantai Cermin kabupaten Solok provinsi Sumatera Barat yang ditanam pada ketinggian 1680 mdpl.

Gubuk Coffee Central mulai beroperasi sejak 14 September 2014 silam. Meskipun belum lama berdiri, hingga bulan Agustus tahun 2018 Gubuk Coffee sudah mempunyai 20 Franchise yang tersebar di 8 provinsi di Indonesia. Selain itu, juga diikuti oleh peningkatan omset pada Gubuk Coffee Central setiap tahunnya. Namun jika ditinjau dari omset bulanannya Gubuk Coffee Central memiliki omset yang tidak tetap setiap bulannya. Trend penjualan produk Gubuk Coffee Central masih dirasakan berfluktuatif, meskipun cenderung meningkat. Selain itu , Gubuk Coffee Central juga memiliki jumlah 
konsumen yang relatif lebih rendah dibandingkan dengan beberapa cabang Gubuk Coffee lainnya.

Berdasarkan perumusan masalah tersebut maka penelitian ini bertujuan untuk :

1. Mendeskripsikan gambaran kepuasan konsumen minuman kopi Arabika Lolo berdasarkan bauran pemasaran pada kafe Gubuk Coffee Central.

2. Menganalisis faktor-faktor yang mempengaruhi kepuasan konsumen terhadap minuman kopi Arabika Lolo pada kafe Gubuk Coffee Central.

\section{METODE PENELITIAN}

Penelitian ini dilakukan di Gubuk Coffee Central yang terletak di Jalan Sudirman No.75 kelurahan Balai Gadang Koto Nan Gadang Payakumbuh Utara, Kota Payakumbuh, Sumatera Barat. Pemilihan lokasi dilakukan dengan sengaja (purposive) dengan pertimbangan bahwa Gubuk Coffee Central merupakan pelopor waralaba coffee shop di Sumatera Barat. Selain itu pemilik (owner) Gubuk Coffee Central juga sekaligus merupakan pewaralaba (Franchisor) dari PT. Gubuk Coffee. Metode penelitian yang digunakan dalam penelitian ini adalah metode survei. Metode pengambilan sampel menggunakan rumus slovin sehingga sampel yang diperoleh berjumlah 97 responden. menggunakan metode puposive sampling. Data yang dikumpulkan dalam penelitian ini adalah data primer dan data sekunder. Data primer diperoleh dari sumber (sampel) melalui wawancara dengan menggunakan kuesioner yang telah dipersiapkan serta melakukan pengamatan langsung di lapangan. Data sekunder adalah data yang diperoleh data yang diperoleh dari instansi terkait, serta literatur-literatur yang berhubungan dengan penelitian ini. Data dalam penelitian ini dianalisis secara deskriptif kuantitatif yang digunakan untuk memperoleh informasi terkait gambaran kepuasan konsumen dan faktor-faktor yang mempengaruhi kepuasan konsumen minuman

124 Laelatul Rahmi et.al. kopi Arabika Lolo menggunakan uji regresi linier berganda melalui aplikasi SPSS For Windows.

\section{HASIL DAN PEMBAHASAN}

\section{Gambaran Umum Kafe Gubuk Coffee}

Gubuk Coffee merupakan suatu waralaba lokal (franchise) coffee shop dan roastery pertama di Sumatera Barat dan menerapkan sistem tanpa rolyalti (royalty fee) pada omset yang diperoleh setiap cabang. Gubuk Coffee Central yang terletak di Jalan Sudirman No.75 kelurahan Balai Gadang Koto Nan Gadang Payakumbuh Utara, Kota Payakumbuh, Sumatera Barat merupakan gerai Gubuk Coffee pertama yang didirikan dan dikelola langsung oleh pewaralaba (franchisor). Usaha franchise coffee shop PT.Gubuk Coffee ini didirikan oleh Bapak Deni Atmam SH, alumni S1 Fakultas Hukum Universitas Andalas, selaku Direktur sekaligus Founder PT.Gubuk Coffee. Usaha ini sudah mulai beroperasi sejak 14 September 2014 silam.

\section{Karakteristik Konsumen}

\section{Karakteristik Konsumen Berdasarkan Usia}

Berdasarkan Tabel 1 diatas, diketahui bahwa responden yang membeli minuman kopi Arabika Lolo di dominasi oleh usia $<25$ tahun dengan persentase sebesar $74 \%$. Hal tersebut menunjukkan bahwa konsumen Gubuk Coffee khususnya penikmat kopi Arabika Lolo didominasi oleh konsumen yang bersifat aktif dan konsumtif. Konsumen yang berusia $<25$ tahun pada umumnya merupakan konsumen yang masih berstatus sebagai seorang siswa atau mahasiswa, hal ini didukung oleh lokasi Gubuk Coffee yang berdekatan dengan sekolah, kampus, pusat perbelanjaan dan pemukiman penduduk.

\section{Karakteristik Konsumen Berdasarkan Jenis Kelamin}

Berdasarkan Tabel 1 dapat dinyatakan bahwa secara gender, laki-laki mendominasi persentase sebanyak $83 \%$, kemudian sebanyak $17 \%$ konsumen sisanya berjenis kelamin perempuan. Terdapat selisih yang 
cukup besar antara konsumen laki-laki dengan konsumen perempuan, Hal ini dikarenakan laki-laki cenderung lebih menyukai kopi di banding perempuan.

\section{Karakteristik Konsumen Berdasarkan Status Pernikahan}

Berdasarkan Tabel 1, hasil survei konsumen minuman kopi Arabika Lolo pada Gubuk Coffee didominasi oleh konsumen yang berstatus belum menikah yaitu sebanyak 77 orang atau sebesar $79 \%$. Hal ini didukung oleh data usia responden yang tergolong masih relatif muda yaitu dibawah 25 tahun yang berstatus belum menikah. Pada umumnya konsumen yang belum menikah lebih banyak melakukan kegiatan diluar rumah dibandingkan dengan yang sudah menikah.

\section{Karakteristik Konsumen Berdasarkan Pendidikan Terakhir}

Berdasarkan Tabel 1, dapat disimpulkan bahwa tingkat pendidikan terakhir responden yang paling banyak adalah SMA sebanyak 44 orang dengan presentase sebesar $46 \%$. Hal tersebut menunjukkan bahwa konsumen minuman kopi Arabika Lolo didominasi oleh para mahasiswa yang berarti pendidikan terakhirnya adalah SMA dan pekerja muda yang senang akan bersosialisasi di luar rumah sekaligus menghilangkan kejenuhan akan aktivitas yang telah dilakukan seharian.

\section{Karakteristik Konsumen Berdasarkan Pekerjaan}

Pekerjaan seorang konsumen akan berpengaruh terhadap gaya hidupnya. Seperti yang dapat dilihat bahwa persentase profesi responden yang paling banyak ditemukan adalah sebagai pelajar/mahasiswa yaitu sebesar $31 \%$. Hal diatas menunjukkan bahwa saat ini kalangan pelajar dan pekerja muda sangat menyukai hal yang cepat dan praktis seperti mengonsumsi makanan dan minuman di luar rumah. Selain itu, banyaknya konsumen kedai kopi yang didominasi oleh pelajar dan mahasiswa tidak terlepas dari lokasi kedai kopi yang strategis.

\section{Karakteristik Konsumen Berdasarkan Pendapatan}

Berdasarkan Tabel 1 diatas dapat dilihat bahwa responden kopi Arabika Lolo dengan tingkat pendapatan Rp. $<1.000 .000$ memiliki persentase terbesar yaitu sebesar $24 \%$ atau sebanyak 22 orang. Dimana pada pendapatan tersebut umumnya adalah para pelajar atau mahasiswa yang belum mempunyai pendapatan dan hanya mempunyai uang saku yang diperoleh dari orangtua atau keluarganya, hal ini juga sejalan dengan jumlah responden yang paling dominan pada bagian pertanyaan usia dan pekerjaan, yaitu didominasi oleh usia dan pekerjaan pelajar atau mahasiswa.

\section{Karakteristik Konsumen Berdasarkan Domisili}

Kafe Gubuk Coffee yang berlokasi di Kota Payakumbuh menyebabkan sebagian besar responden kopi Arabika Lolo yaitu dengan persentase sebesar $68 \%$ atau sebanyak 66 orang adalah konsumen yang berdomisili di Payakumbuh. Hal ini dikarenakan Kafe Gubuk Coffee terletak di lokasi yang strategis yaitu terletak di pusat kota sehingga mudah dijangkau oleh konsumen yang berdomisili di Payakumbuh.

\section{Mendeskripsikan Gambaran Kepuasan Konsumen Minuman Kopi Arabika Lolo Berdasarkan Bauran Pemasaran Pada Kafe Gubuk Coffee Central}

\section{Penilaian Konsumen Tehadap Produk $\left(X_{1}\right)$}

Berdasarkan jawaban responden yang paling banyak pada setiap indikator pertanyaan dari 2 tabel di atas, indikator pertama dengan kategori jawaban setuju sebesar 54\% dan skor rata-rata sebesar 4,2 artinya konsumen menilai indikator tersebut sudah berada pada kategori sangat baik. Selanjutnya dari indikator nomor 2 dengan kategori jawaban setuju sebesar $53 \%$ dan skor rata-rata sebesar 4,2, artinya indikator tersebut berada pada kategori sangat baik. Indikator nomor 3 dengan kategori jawaban setuju sebesar $57 \%$ dan skor rata-rata sebesar 4,1, artinya indikator tersebut berada pada kategori baik. Kemudian dilihat dari indikator nomor 4 dengan kategori jawaban

Laelatul Rahmi et.al. 125 
setuju sebesar $55 \%$ dan skor rata-rata sebesar 4,1, artinya indikator tersebut berada pada kategori baik. Indikator nomor 5 merupakan indikator yang memiliki nilai tertinggi dari seluruh indikator variabel produk sekaligus dari variabel bebas yaitu dengan kategori jawaban sangat setuju sebesar 59\% dan skor rata-rata sebesar 4,5 , artinya indikator tersebut berada pada kategori sangat baik. Jika dilihat dari segi pelayanannya yaitu indikator nomor 6 dengan kategori jawaban setuju sebesar 38\% dan skor rata-rata sebesar 3,7, artinya indikator tersebut berada pada kategori baik. Indikator nomor 7 dengan kategori jawaban setuju sebesar $42 \%$ dan skor ratarata sebesar 3,9, artinya indikator tersebut berada pada kategori baik. Selanjutnya indikator nomor 8 dengan kategori jawaban setuju sebesar $45 \%$ dan skor rata-rata sebesar 4, artinya indikator tersebut berada pada kategori baik. Indikator nomor 9 dengan kategori jawaban setuju sebesar $49 \%$ dan skor ratarata sebesar 4,2, artinya indikator tersebut berada pada kategori baik. Kemudian pada indikator nomor 10 dengan kategori jawaban setuju sebesar $49 \%$ dan skor rata-rata sebesar 4,1 , artinya indikator tersebut berada pada kategori baik. Dan untuk indikator y ang terakhir dari variabel produk dengan kategori jawaban setuju sebesar $50 \%$ dan skor rata-rata sebesar 4,1, artinya indikator tersebut berada pada kategori baik. Berdasarkan Tabel 3 di atas, dapat diketahui bahwa penilaian konsumen terhadap produk berada pada kategori baik yaitu sebesar 4,1. Artinya konsumen minuman kopi Arabika Lolo menilai kualitas kopi Arabika Lolo dan kualitas pelayanan yang telah Gubuk Coffee Central berikan sudah baik.

\section{Penilaian Konsumen Terhadap Harga $\left(\mathrm{X}_{2}\right)$}

Untuk pelanggan yang sensitif, biasanya harga murah adalah sumber kepuasan yang penting karena mereka akan mendapatkan value for money yang tinggi. Jawaban responden tentang kualitas harga dapat dilihat pada tabel di bawah ini :

Berdasarkan jawaban responden yang paling banyak pada setiap indikator pertanyaan dari 2 tabel di atas,

126 Laelatul Rahmi et.al. indikator pertama dengan kategori jawaban setuju sebesar $46 \%$ dan skor rata-rata sebesar 4,2, artinya menurut konsumen indikator tersebut berada pada kategori sangat baik. Kemudian untuk indikator yang kedua dengan kategori jawaban setuju sebesar 50\% dan skor rata-rata sebesar 4,3, artinya indikator tersebut berada pada kategori sangat baik. Berdasarkan Tabel 5 di atas, dapat diketahui bahwa tingkat kepuasan konsumen terhadap harga berada pada kategori sangat baik yaitu sebesar 4,25. Artinya konsumen minuman kopi Arabika Lolo menilai bahwa harga minuman kopi Arabika Lolo terjangkau bagi konsumen dan harga tersebut juga sesuai dengan kualitas dan pelayanan yang diberikan Gubuk Coffee Central.

\section{Penilaian Konsumen Terhadap Tempat $\left(X_{3}\right)$}

Berdasarkan jawaban responden yang paling banyak pada setiap indikator pertanyaan dari 2 tabel di atas, indikator pertama dengan kategori jawaban sangat setuju sebesar $57 \%$ dan skor rata-rata sebesar 4,4, artinya konsumen menilai indikator tersebut berada pada kategori sangat baik, indikator ini merupakan indikator dengan jumlah jawaban tertinggi kedua dari seluruh indikator variabel bebas sekaligus menjadi nilai yang tertinggi dari seluruh indikator variabel tempat. Selanjutnya indikator nomor 2 dengan kategori jawaban sangat setuju sebesar 52\% dan skor rata-rata sebesar 4,3 , artinya indikator tersebut berada pada kategori sangat baik, indikator ini merupakan indikator dengan jumlah jawaban tertinggi ketiga dari seluruh indikator variabel bebas sekaligus menjadi nilai yang tertinggi kedua dari seluruh indikator variabel tempat. Indikator nomor 3 dengan kategori jawaban setuju sebesar $47 \%$ dan skor rata-rata sebesar 4,2, artinya indikator tersebut berada pada kategori sangat baik. Dilihat dari indikator nomor 4 dengan kategori jawaban setuju sebesar $49 \%$ dan skor rata-rata sebesar 4, artinya indikator tersebut berada pada kategori baik. Indikator nomor 5 dengan kategori jawaban netral sebesar $44 \%$ dan skor rata-rata sebesar 3,6, artinya indikator tersebut berada pada kategori baik. Indikator nomor 6 dengan kategori jawaban setuju 
sebesar $45 \%$ dan skor rata-rata sebesar 3,8, artinya indikator tersebut berada pada kategori baik. Untuk indikator nomor 7 dengan kategori jawaban setuju sebesar 39\% dan skor rata-rata sebesar 3,7, artinya indikator tersebut berada pada kategori baik. Indikator terakhir dengan kategori jawaban setuju sebesar 39\% dan skor rata-rata sebesar 3,8, artinya indikator tersebut berada pada kategori baik. Berdasarkan Tabel 7 diatas, dapat diketahui bahwa tingkat kepuasan konsumen terhadap tempat berada pada kategori baik yaitu sebesar 3,97. Artinya konsumen minuman kopi Arabika Lolo menilai bahwa semua atribut tentang tempat pada Gubuk Coffee Central sudah baik .

\section{Penilaian Konsumen Terhadap Promosi $\left(\mathrm{X}_{4}\right)$}

Berdasarkan jawaban responden yang paling banyak pada setiap indikator pertanyaan dari 2 tabel di atas, indikator pertama dengan kategori jawaban setuju sebesar $47 \%$ dan skor rata-rata sebesar 4,1, artinya adalah menurut konsumen indikator tersebut berada pada kategori baik. Indikator nomor 2 dengan kategori jawaban netral sebesar $43 \%$ dan skor ratarata sebesar 3,1, artinya indikator tersebut berada pada kategori cukup baik. Indikator nomor 3 dengan kategori jawaban setuju sebesar $40 \%$ dan skor ratarata sebesar 3,8, artinya indikator tersebut berada pada kategori baik. Indikator terakhir dengan kategori jawaban setuju sebesar 53\% dan skor ratarata sebesar 3,9, artinya indikator tersebut berada pada kategori baik.Berdasarkan Tabel 9 di atas, dapat diketahui bahwa tingkat kepuasan konsumen terhadap kualitas promosi berada pada kategori baik yaitu sebesar 3,72. Artinya konsumen minuman kopi Arabika Lolo menilai promosi yang telah dilakukan Gubuk Coffee Central selama ini sudah baik.

\section{Analisis Kepuasan Konsumen (Y)}

Berdasarkan Tabel 10 d iatas, diketahui jawaban responden tentang kepuasan konsumen rata-rata menjawab kurang setuju sebanyak $0,6 \%$. Kemudian jumlah yang memilih netral sebanyak $16 \%$, setuju sebanyak $49,4 \%$ dan sangat setuju sebanyak $34 \%$. Dilihat berdasarkan jawaban responden yang paling banyak pada setiap indikator pertanyaan dari 2 tabel diatas, indikator pertama dengan kategori jawaban setuju sebesar $52 \%$ dan skor rata-rata sebesar 4,2, artinya adalah indikator tersebut berada pada kategori sudah sangat baik. Indikator nomor 2 dengan kategori jawaban setuju sebesar 53\% dan skor rata-rata sebesar 4,2, artinya indikator tersebut berada pada kategori sudah sangat baik. Indikator nomor 3 dengan kategori jawaban setuju sebesar $49 \%$ dan skor rata-rata sebesar 4, artinya indikator tersebut berada pada kategori baik. Dilihat dari indikator nomor 4 dengan kategori jawaban setuju sebesar $45 \%$ dan skor rata-rata sebesar 4,3, artinya indikator tersebut berada pada kategori sangat baik. Kemudian untuk indikator yang terakhir dengan kategori jawaban setuju sebesar $48 \%$ dan skor ratarata sebesar 4,2, artinya indikator tersebut berada pada kategori sangat baik. Berdasarkan Tabel 11 di atas, dapat diketahui bahwa tingkat kepuasan konsumen berada pada kategori puas yaitu sebesar 4,18 . yang mana angka tersebut hampir mendekati angka pada kategori sangat puas. Hal ini menandakan bahwa konsumen minuman kopi Arabika Lolo pada kafe Gubuk Coffee Central dinilai puas dengan kualitas produk dan layanan yang ditawarkan, yaitu mencakup kualitas produk, kualitas harga, kualitas tempat, dan kualitas promosi yang telah diberikan oleh kafe Gubuk Coffee Central kepada konsumennya.

\section{Menganalisis Faktor-Faktor Yang Mempengaruhi Kepuasan Konsumen Terhadap Minuman Kopi Arabika Lolo Pada Kafe Gubuk Coffee Central}

\section{Uji Asumsi Klasik}

Langkah pertama dilakukan uji normalitas, pengujian dilakukan dengan metode Kolmogorov-Smirnov (KS). Dari hasil analisis data yang dilakukan, menunjukkan bahwa nilai signifikansi adalah 0,56 > 0,05. Maka dapat diartikan bahwa data tersebut berdistribusi normal. Langkah kedua yaitu dilakukan uji multikolinearitas, tujuannya untuk mengetahui apakah pada model regresi terdapat korelasi antar variabel independen. 
Dari hasil pengujian multikolinearitas yang dilakukan diketahui bahwa nilai VIF yaitu lebih kecil dari 10, sehingga bisa disimpulkan bahwa tidak ada multikolinearitas antar variabel independen dalam model regresi.

Langkah ketiga yaitu dilakukan uji heteroskedastisitas, bertujuan untuk menguji apakah dalam model regresi terjadi ketidaksamaan varian dari residual satu pengamatan ke pengamatan yang lainnya.

Berdasarkan Tabel $13 \mathrm{~d}$ iatas dapat disimpulkan bahwa nilai signifikansi dari 4 variabel adalah > 0,05 yang artinya tidak terjadi masalah heteroskedastisitas dalam model regresi.

\section{Uji F (Uji Simultan)}

Dari hasil analisis data yang dilakukan, menunjukkan bahwa hasil signifikansi sebesar Nilai Mean Square Regression sebesar $0,000<0,1$ dan dapat dilihat nilai Fhitung sebesar 36,791 Jadi Fhitung > Ftabe $(36,791>2,006)$. Maka dari analisis diatas dapat disimpulkan bahwa secara simultan (bersama-sama) variabel bebas produk $\left(X_{1}\right)$, harga $\left(X_{2}\right)$, tempat $\left(X_{3}\right)$, dan promosi $\left(\mathrm{X}_{4}\right)$ berpengaruh signifikan terhadap variabel kepuasan konsumen minuman kopi Arabika Lolo (Y) pada kafe Gubuk Coffee Central di Payakumbuh.

\section{Uji Parsial}

Nilai $\mathrm{R}^{2}$ yang diperoleh pada penelitian ini adalah sebesar 0,615 artinya variabel kepuasan konsumen dapat dijelaskan oleh sekelompok variabel bebas yang terdiri dari produk, harga, tempat, dan promosi secara serentak atau simultan sebesar $62 \%$ sedangkan $38 \%$ sisanya dijelaskan oleh variabel lain diluar model yang tidak diteliti.

Dari hasil analisis regresi linear berganda didapatkan persamaan sebagai berikut:

$$
\begin{aligned}
& Y=a+b 1 X 1+b 2 X 2+b 3 X 3+b 4 X 4+e \\
& Y=3,501+0,236 X 1+0,284 X 2+0,077 X 3+ \\
& 0,120 X 4+1,452
\end{aligned}
$$

Hasil dari output tabel di atas dapat dijelaskan sebagai berikut :

1. Konstanta sebesar 3,501 menyatakan bahwa apabila tidak ada faktor produk $\left(\mathrm{X}_{1}\right)$, harga $\left(\mathrm{X}_{2}\right)$, tempat $\left(\mathrm{X}_{3}\right)$ dan promosi $\left(\mathrm{X}_{4}\right)$ maka kepuasan konsumen (Y) minuman kopi Arabika Lolo akan tetap ada dengan nilai kepuasan sebesar 3,501 yang artinya berada pada kategori puas.

2. Koefisien regresi pada variabel produk adalah bernilai positif sehingga dapat dikatakan bahwa semakin tinggi tingkat skor penilaian konsumen terhadap kualitas produk maka akan semakin tinggi pula tingkat kepuasan konsumen degan nilai sebesar 0,236. Dapat juga diartikan apabila setiap kenaikan kualitas produk sebesar satu satuan maka variabel kepuasan konsumen akan naik sebesar 0,236 satuan dengan asumsi bahwa variabel bebas yang lainnya adalah tetap. Berdasarkan hasil uji parsial, diketahui bahwa variabel produk berpengaruh signifikan terhadap kepuasan konsumen.

3. Koefisien regresi pada variabel harga adalah bernilai positif sehingga dapat dikatakan bahwa semakin terjangkau harga dan semakin tinggi tingkat kesesuaian harga dengan kualitas minuman kopi Arabika Lolo yang ditawarkan maka tingkat kepuasan konsumen akan semakin tinggi sebesar 0,284. Dapat juga diartikan apabila setiap harga minuman kopi Arabika Lolo yang ditetapkan lebih terjangkau dan lebih sesuai sebesar satu satuan maka akan meningkatkan kepuasan konsumen sebesar 0.284 satuan dengan asumsi bahwa variabel bebas yang lainnya adalah tetap. Berdasarkan hasil uji parsial, diketahui bahwa variabel harga juga berpengaruh signifikan terhadap kepuasan konsumen.

4. Koefisien regresi pada variabel tempat juga bernilai positif sehingga dapat dikatakan bahwa semakin tinggi tingkat skor penilaian konsumen terhadap kenyamanan tempat kafe Gubuk Coffee Central maka akan semakin tinggi tingkat kepuasan konsumen dengan nilai sebesar 0,077. Dapat juga diartikan bahwa setiap kenaikan kualitas tempat sebesar satu satuan maka kepuasan 
konsumen akan naik sebesar 0,077 satuan dengan asumsi bahwa variabel bebas yang lainnya adalah tetap. Berdasarkan hasil uji parsial, diketahui bahwa variabel tempat tidak berpengaruh signifikan terhadap kepuasan konsumen.

5. Koefisien regresi pada variabel promosi jug a bernilai positif sehingga dapat dikatakan bahwa semakin menarik dan semakin banyaknya promosi yang dilakukan, maka tingkat kepuasan konsumen akan semakin tinggi dengan nilai sebesar 0,120. Dapat juga diartikan setiap kafe Gubuk Coffee semakin aktif melakukan promosi terhadap minuman kopi Arabika Lolo, baik melalui media sosial maupun melalui mulut ke mulut sebesar satu satuan maka variabel kepuasan konsumen akan naik sebesar 0,120 satuan dengan asumsi bahwa variabel bebas yang lainnya adalah tetap. Berdasarkan hasil uji parsial, diketahui bahwa variabel promosi juga tidak berpengaruh signifikan terhadap kepuasan konsumen.

\section{KESIMPULAN DAN SARAN}

\section{Kesimpulan}

Tingkat kepuasan konsumen minuman kopi Arabika Lolo pada Kafe Gubuk Coffee Central berada pada kategori puas dengan nilai skor rata-rata sebesar 4,18. Jika dilihat dari variabel bauran pemasaran diketahui bahwa semua variabel memiliki nilai skor rata-rata yang berada pada kategori baik untuk variabel produk, tempat, dan harga, dan kategori sangat baik untuk variabel harga.

Berdasarkan hasil analisis diketahui bahwa variabel yang berpengaruh signifikan terhadap kepuasan konsumen minuman kopi Arabika Lolo adalah variabel produk dan variabel harga, sedangkan variabel tempat dan variabel promosi tidak berpengaruh signifikan terhadap kepuasan konsumen minuman kopi Arabika Lolo.

\section{SARAN}

Untuk meningkatkan kepuasan konsumen terhadap minuman kopi Arabika Lolo, kafe Gubuk Coffee
Central perlu mempertahankan kualitas produk dan mempertahankan kesesuaian harga kopi dengan kualitas yang diberikan. Kemudian Gubuk Coffee Central perlu memperbaiki faktor-faktor yang mempengaruhi kepuasan konsumen lainnya yaitu tempat dan promosi.

Melakukan survey kepuasan konsumen secara berkala untuk mengetahui kinerja produk dan pelayanan yang ditawarkan. Salah sau cara yang bisa dilakukan adalah penyediaan kotak saran pada kafe.

\section{Daftar Pustaka}

Adityo, Danny et al. . (2014. ). Pengaruh Karakteristik Situasional dan Komponen Kualit as Layanan Gera i Starbucks terhadap Keputusan Pembelian Ulang. Jurnal Manajemen Agribisnis, 2, 49-60.

AEKI. (2018). Asosiasi Eksportir Kopi Indonesia. . http://www.aeki-aice.org/. 